\title{
Exposure of Laboratory Mice to Domestic Cooking Gas: - Implications for Toxicity
}

\author{
Oyeronke A. Odunola ${ }^{1}$, Emmanuel Uka ${ }^{1}$, Kazeem A. Akinwumi ${ }^{1,2}$, Michael A. Gbadegesin ${ }^{1}$, Olabode O. Osifeso ${ }^{1}$ and \\ Madu D. Ibegbu ${ }^{1,3}$ \\ ${ }^{1}$ Cancer Research and Molecular Biology Laboratories, Department of Biochemistry, College of Medicine, University of \\ Ibadan, Ibadan, Nigeria \\ ${ }^{2}$ Department of Chemical Sciences, College of Natural and Applied Sciences, Bells University of Technology, Ota, Nigeria \\ ${ }^{3}$ Department of Medical Biochemistry, University of Nigeria, Enugu Campus, Enugu, Nigeria \\ *Correspondence to Dr. Oyeronke A. Odunola. E-mail: ronodunola@yahoo.com
}

Received: 11 January 2008 / Accepted: 24 July 2008 / Published: 30 September 2008

\begin{abstract}
The ability of domestic cooking gas to induce hepatotoxicity and clastogenicity in mice was studied. The mice were exposed to domestic gas for twenty-one days at doses of $100 \mathrm{mg} / \mathrm{kg}, 200 \mathrm{mg} / \mathrm{kg}$ and $300 \mathrm{mg} / \mathrm{kg}$ respectively. The positive control group of mice were given sodium arsenite intraperitoneously at a dose of $2.5 \mathrm{mg} / \mathrm{kg}$ body weight. While the negative control group had only distilled water, sodium arsenite significantly $(\mathrm{p}<0.05)$ induced the formation of micronucleated polychromatic erythrocytes (mPCEs), serum and liver gamma glutamyl transferase $(\gamma \mathrm{GT})$ and alkaline phosphatase (AP) activities respectively as compared with the observations made in the negative control group. Similarly, the domestic gas significantly $(\mathrm{p}<0.05)$ induced mPCEs formation, serum and liver, $\gamma \mathrm{GT}$ and AP activities. The degree of induction was in the order of $100 \mathrm{mg} / \mathrm{kg}<200 \mathrm{mg} / \mathrm{kg}<300 \mathrm{mg} / \mathrm{kg}$. However, when compared with the positive control group, the domestic cooking gas at the tested doses was not as potent as sodium arsenite in its ability to induce enzyme activity and mPCEs formation. Limited histopathological analysis of liver samples from treated and untreated mice showed distended blood vessels, necrosis and hepatocellular degeneration in the groups treated with high doses of domestic gas or sodium arsenite as compared with the untreated group. Our findings suggest that the domestic cooking gas has some degree of clastogenic and hepatotoxic activities in mice. Health risks may therefore be associated with long-term occupational and / or domestic exposure in humans.
\end{abstract}

Keywords: Domestic cooking gas, sodium arsenite, micronucleated polychromatic erythrocyte, $\gamma$-GT and AP, mice.

\section{Introduction}

Domestic cooking gas (DCG) is a colorless liquefied petroleum gas with mild odor extracted from crude oil. It is composed of a family of light chain hydrocarbons especially propane and butane as well as their alkenes derivatives mixed in varying proportion [1]. Ethane thiol is usually added to give the mild odor. For some decades, DCG has been the fuel of choice for hundreds of millions of people around the world. This is basically because of its perceived non-toxicity, convenience; clean burning and high calorific value [1]. Consequently therefore, exposure to cooking gas in homes occurs as a result of leakages from the storage cylinder and during cooking in the kitchen [2]. In addition, occupational accidental exposure to the gas during processing, transportation and storage cannot be ruled out.

Information exists in literature on the toxic effect of exposure to DCG. Such effects include asphyxiation, nausea, malaise, and general weakness of lower limbs [3, 4]. Abnormal liver function and neurological effect as well as rhabdomyolysis have also been reported [5-7]. Similarly, Fukunaga et al [8] reported the death of two men during accidental occupational exposure to liquefied petroleum gas. There is however a dearth of information on the genotoxic effect of DCG in laboratory animals and man.

In this connection, we assess the genotoxicity of domestic cooking gas in mouse bone marrow cells using the micronucleus assay. In addition, we also assessed its effect on the liver by monitoring the activities of serum 
and liver gamma glutamyl transferase $(\gamma$-GT) and alkaline phosphatase (AP). Limited histopathology of the liver samples was also carried out.

\section{Materials and Methods}

\section{Test Materials}

Domestic cooking gas was purchased from Total Filling Station, Total Garden, Ibadan, Oyo state. Sodium arsenite $\left(\mathrm{Na}_{2} \mathrm{AsO}_{2}\right.$, Mol.wt 129.9 As 57.6\% CAS No 7784-46-5) was from Sigma Chemical Co., St. Louis, MO. The concentration of sodium arsenite was made to $1 / 10$ th of its $\mathrm{LD}_{50}$, (i.e. $2.5 \mathrm{mg} / \mathrm{kg}$ ). Gamma-glutamyl Transferase $(\gamma$ GT) and Alkaline Phosphatase (AP) kits were obtained from Randox Laboratory India. All other reagents and chemicals are of analytical grade and were obtained from Sigma Chemical Co. St. Louis, MO., USA.

\section{Experimental Animals}

Twelve weeks old male mice with average weight of $200 \mathrm{~g}$, and no sign of diseases or injury were used. They were kept in the Experimental Animal House, Department of Biochemistry, University of Ibadan. They were divided into five groups of five mice each. The mice in Group I served as the negative control and was fed with distilled water throughout the experiment. Those in Group II were injected interperitoneally with $2.5 \mathrm{mg} / \mathrm{kg}$ body weight of sodium arsenite on the last day of the experiment. Group III, IV and V animals were exposed to $100 \mathrm{mg} / \mathrm{kg}, 200$ $\mathrm{mg} / \mathrm{kg}$ and $300 \mathrm{mg} / \mathrm{kg}$ of domestic cooking gas respectively.

All the mice had free access to pellets from Ladokun Livestock Feeds Limited, Ibadan, Nigeria and water ad libitum. The mice were allowed to acclimatize for seven days before commencement of the experiment with 12 hours light/ dark cycle and temperature of $29 \pm 2{ }^{\circ} \mathrm{C}$. These conditions were maintained throughout the duration of the experiment.

\section{Exposure of Mice to Cooking Gas}

Three nominally identical wooden exposure chambers with internal volume of approximately six litres were used. The mice were exposed to $100 \mathrm{mg} / \mathrm{kg}, 200 \mathrm{mg} / \mathrm{kg}$ and $300 \mathrm{mg} / \mathrm{kg}$ of DCG whole body for eight hours per day making a total of twenty one exposures over a three week period. The lowest concentration of the gas of (i.e. $100 \mathrm{mg} / \mathrm{kg}$ ) corresponds to $1 / 10$ th of the permissible occupational exposure limit of liquefied petroleum gas in humans [9, 10]. Sodium arsenite was injected interperitoneally at $2.5 \mathrm{mg} / \mathrm{kg}$ to group II mice on the last day of exposure. Twenty-four hours after the last exposures to DCG and treatment with sodium arsenite, the mice were sacrificed by cervical dislocation and blood collected directly from the heart by cardiac puncture. Liver and femur samples were collected for biochemical analyses, pathological examination and micronucleus assay respectively.

\section{Micronucleus Assay}

Clastogenic effects were evaluated in the mouse bone marrow using the micronucleus.assay as described by Heddle and Salmone, [11] and modified by Heddle et al [12]. The femurs from each of the animals were removed and bone marrow was aspirated with a syringe and microscopic slides prepared as described. The slides were fixed, air-dried and pretreated with May-Gruenwald solution. The dried slides were stained in 5\% Giemsa solution and induced in phosphate buffer for 30 seconds. Thereafter they were rinsed in distilled water, air-dried and mounted on DPX for proper drying. The slides were scored under the microscope for micronucleated polychromatic erythrocytes (mPCEs).

\section{Histological Analysis}

Liver sections were fixed in 4\% $\mathrm{P}$ - formaldehyde and washed in phosphate buffer $\mathrm{pH} 7.4$ at $4^{\circ} \mathrm{C}$ for 12 hours. After dehydration, the tissue was embedded in paraffin, cut into 5-um sections, stained with haematoxylin- eosin dye and finally observed under a photo microscope.

\section{Enzyme Assay}

Serum was prepared from blood that had been allowed to clot at room temperate for two hours. The clotted blood samples were centrifuged at 3,000 $\mathrm{g}$ for 10 minutes after which the supernatant, which is the serum, was decanted and used immediately or stored at $-20^{\circ} \mathrm{C}$ until required. Livers were washed in ice cold $1.15 \%$ potassium chloride $(\mathrm{KCl})$ and weighed. They were then homogenized in 4 volumes of homogenizing buffer containing $50 \mathrm{mM}$ Tris- $\mathrm{HCl}$ mixed with $1.15 \% \mathrm{KCl}$ using a Teflon homogenizer. The homogenate was centrifuged at $10,000 \mathrm{~g}$ for 20 minutes. The supernatant which is the post- mitochondria fraction was stored at $-20^{\circ} \mathrm{C}$ until when needed for analysis. Gamma-glutamyl transferase $(\gamma-\mathrm{GT})$ activity was assayed in the serum and liver homogenates by using the reconstituted $\gamma$-GT reagent following the method of Szasz [13]. $0.5 \mathrm{ml}$ of the serum or liver homogenate was mixed with $0.05 \mathrm{ml}$ of the reconstituted reagent. The absorbance of the mixture was read at $405 \mathrm{~nm}$ four times with a minute interval between the readings.

The mean changes in absorbance per minute were then obtained. Alkaline phosphatase (AP) activity was also assayed in the serum and liver homogenate using the reconstituted AP reagent from Randox Laboratory India. $2.5 \mathrm{ml}$ of the reagent at $25^{\circ} \mathrm{C}$ was mixed with $0.05 \mathrm{ml}$ of the sample. The mixture was then incubated at $25^{\circ} \mathrm{C}$ the absorbance of the mixture was read twice at a minute interval at $405 \mathrm{~nm}$. The change in absorbance per minute was then estimated. 


\section{Statistical Analysis}

The data were analysed by One-Way Way Analysis of Variance (ANOVA) followed by Duncan Multiple Range test. $\mathrm{P}$ values less than 0.05 were considered statistically significant.

\section{Results}

Effects of Sodium Arsenite and Exposure to DCG on Bone Marrow Cells

The number of micronucleated polychromatic erythrocytes (mPCEs) per 1000 polychromatic erythrocytes induced in the bone marrow of the mice treated with sodium arsenite is significant higher $(\mathrm{P}<0.05)$ than that of the negative control group, given distilled water only (Table 1). The increase was about 17 folds. The domestic gas also at all the tested concentrations significantly induced mPCEs formation as compared with the negative control group. The increase was by 8,9 and 13 folds in animals exposed to 100,200 and $300 \mathrm{mg} / \mathrm{kg}$ of DCG respectively.

Table 1: The effect of cooking gas on the induction of micronucleated polychromatic erythrocytes mPCEs in mice

\begin{tabular}{llr}
\hline Group & Treatment & $\begin{array}{r}\text { No. of } \begin{array}{r}\text { mPCEs per } \\
1000 \text { PCES } \\
\text { Mean } \pm \text { S.EM }\end{array} \\
\text { I }\end{array}$ \\
II & Distilled Water & $0.20 \pm 0.20$ \\
III & Sodium Arsenite & $5.20 * \pm 0.73$ \\
IV & $\begin{array}{l}\text { Domestic Cooking } \\
\text { Gas }(100 \mathrm{mg} / \mathrm{kg})\end{array}$ & $1.60 * \pm 0.25$ \\
V & $\begin{array}{l}\text { Domestic Cooking } \\
\text { Gas }(200 \mathrm{mg} / \mathrm{kg})\end{array}$ & $1.80 * \pm 0.37$ \\
& $\begin{array}{l}\text { Domestic Cooking } \\
\text { Gas }(300 \mathrm{mg} / \mathrm{kg})\end{array}$ & $2.60 * \pm 0.25$ \\
\hline
\end{tabular}

*Values are significantly greater than the negative control $\mathrm{P}<0.05$

The Effect of Sodium Arsenite and Exposure to DCG on Serum and Liver Gamma-Glutamyl Transferase (Tgt) and Alkaline Phosphatase Activities

Treatment with sodium arsenite alone significantly increased the $\gamma$-GT activity in the serum and liver of the group II animals $(p<0.05)$ as compared with what was observed in the negative control rats treated with distilled water alone (Table 2). Similar observation was made for the rats treated with the DCG at different concentration, (groups III, IV and V). The increases were significantly different $(p<0.05)$ from the value observed for the negative control group.
Table 2: The effect of domestic cooking gas on serum (S) and liver (L) $\gamma$-glutamyl transferase activity in mice

\begin{tabular}{llcr}
\hline Group & Treatment & $\begin{array}{l}S \gamma-G T(U / L) \\
\text { Mean } \pm \text { S.EM }\end{array}$ & $\begin{array}{l}\text { L } \gamma \text {-LT }(U / L) \\
\text { Mean } \pm \text { S.EM }\end{array}$ \\
\hline I & Distilled water & $2.39 \pm 0.16$ & $3.03 \pm 0.08$ \\
II & Sodium Arsenite & $11.39^{*} \pm 0.31$ & $17.88^{*} \pm 0.29$ \\
III & $\begin{array}{l}\text { Domestic } \\
\text { Cooking Gas } \\
(100 \mathrm{mg} / \mathrm{kg})\end{array}$ & $3.71 \pm 0.16$ & $4.24 \pm 0.21$ \\
IV & $\begin{array}{l}\text { Domestic } \\
\text { Cooking Gas } \\
(200 \mathrm{mg} / \mathrm{kg})\end{array}$ & $4.24^{*} \pm 0.20$ & $5.45^{*} \pm 0.18$ \\
$\mathrm{~V}$ & $\begin{array}{l}\text { Domestic } \\
\text { Cooking Gas } \\
(300 \mathrm{mg} / \mathrm{kg})\end{array}$ & $5.15^{*} \pm 0.10$ & $6.36^{*} \pm 0.28$ \\
\hline
\end{tabular}

*Values are significantly greater than the negative control $\mathrm{P}<0.05$

Observations made with liver and serum AP activity were similar to the pattern observed for the $\gamma$-GT activity. The mice exposed to sodium arsenite or DCG have increased AP activity than the negative control treated with distilled water only. The increase in liver and serum AP activities are significantly $(\mathrm{p}<0.05)$ higher than what was observed for the negative control group (Table 3 ). The increase in activity of the two enzymes by DCG is dose dependent. However, the activity of both enzymes in the serum and liver was greater in mice exposed to sodium arsenite as compared with those treated with the various concentration of DCG.

TABLE 3: The effect of domestic cooking gas on serum (S) and liver (L) Alkaline Phosphatase activity in mice

\begin{tabular}{llcr}
\hline Group Treatment & $\begin{array}{c}\text { SAP }(\mathrm{U} / \mathrm{L}) \\
\text { Mean } \pm \text { S.EM }\end{array}$ & $\begin{array}{c}\text { LAP }(\mathrm{U} / \mathrm{L}) \\
\text { Mean } \pm \text { S.EM }\end{array}$ \\
\hline I & Distilled Water & $14.95 \pm 0.26$ & $17.61 \pm 0.56$ \\
II & Sodium Arsenite & $45.57 * \pm 0.66$ & $56.26 * \pm 1.60$ \\
III $\quad \begin{array}{l}\text { Domestic Cooking } \\
\text { Gas }(100 \mathrm{mg} / \mathrm{kg})\end{array}$ & $23.85 * \pm 0.49$ & $30.87 *^{*} 0.70$ \\
IV $\quad \begin{array}{l}\text { Domestic Cooking } \\
\text { Gas }(200 \mathrm{mg} / \mathrm{kg})\end{array}$ & $30.43^{*} \pm 0.67$ & $37.68 * \pm 0.70$ \\
V & $\begin{array}{l}\text { Domestic Cooking } \\
\text { Gas }(300 \mathrm{mg} / \mathrm{kg})\end{array}$ & $35.91 * \pm 0.76$ & $42.24 * \pm 0.53$
\end{tabular}

*Values are significantly greater than the negative control $\mathrm{P}<0.05$ 


\section{Discussion}

Exposure of man and animals to petroleum products is known to occur on a continuous basis. Even the early men were exposed to heavy smokes from cooking, wood and bush burning. Such smokes are now known to contain hydrocarbons and other harmful substances such as nitrogen IV oxide and ultrafine particles [14]. Some hazardous effects of DCG in exposed animals have also been documented [15]. Effects of chronic exposure of laboratory mice to DCG were examined in this study. The mouse bone marrow micronucleus (MN) assay, a predictive index for evaluating the carcinogenic potential of environmental and occupational chemical exposure was used $[16,17]$. Our results clearly indicate that all the three doses of DCG studied significantly $(\mathrm{P}<0.05)$ induced the formation of micronuclei in the polychromatic erythrocytes (PCEs) of the mice bone marrow cells (Table 3 ). The induction was about 8,9 and 13 folds in mice exposed to $100 \mathrm{mg} / \mathrm{kg}, 200 \mathrm{mg} / \mathrm{kg}$ and $300 \mathrm{mg} / \mathrm{kg}$ respectively. This suggests a dose dependent relationship. The increase in the frequency of formation of micronuclei observed by DCG in this study as compared to the negative control may be an evidence of clastogenic potential of the gas. Environmental contaminants and clastogens are known to influence the formation of micronuclei by inducing chromosomal breaks and interfering with spindle formation $[18,19]$. Consequently therefore, long-term exposure to domestic cooking gas may be deleterious especially in man.

Gamma glutamyl transferase $(\gamma-$ GT) and alkaline phosphatase (AP) activities have been used in the diagnosis hepatic injury. The activity of these enzymes is known to increase in the liver and serum as a result of hepatic damage or injury [20]. The result obtained for $\gamma$ GT activity show a 1.6, 1.8 and 2.2 folds rise in mice exposed to $100 \mathrm{mg} / \mathrm{kg}, 200 \mathrm{mg} / \mathrm{kg}$ and $300 \mathrm{mg} / \mathrm{kg}$ of DCG respectively, while the activity was raised by about to 1.4 , 1.5 and 2.1 folds in the liver in the same set of mice when compared to the negative control (Table 2). This may not only be an indication of hepatoxicity, but also of oxidative stress. Increased activity of $\gamma$-GT has been associated with hepatoxicity, oxidative stress and chromosomal aberrations in cells [21-23].

Although Ukaejiofo et al [24] reported a significant decrease in serum AP of refinery workers exposed to DCG, our result show a significant $(\mathrm{P}<0.05) 1.6,2$ and 2.4 fold rise in serum AP activity and 1.8, 2.1.and 2.4 folds rise in liver AP in mice exposed to $100 \mathrm{mg} / \mathrm{kg}, 200 \mathrm{mg} / \mathrm{kg}$ and $300 \mathrm{mg} / \mathrm{kg}$ respectively as compared with the negative control. The increase in the activity of the two enzymes by domestic gas is dose dependent.

The decreased serum AP observed in workers exposed to liquefied petroleum gas [24] may be as a result of confounding petrol chemicals that refinery workers are exposed to along side DCG. Species differences between man and mice may also account for the differences in the results.
The result of the histopathological analysis in the liver of mice exposed to DCG (Table 4) may be an evidence of direct toxicities to hepatic tissue. This may be attributed to the major component of DCG like butane and propane. Both gases have been separately shown to bind and inflict injury directly or indirectly to liver cells [2528]. It may also complement the increase in activities of serum and liver $\gamma$ - GT as well as ALP earlier observed in DCG exposed mice. Our findings here suggest that domestic cooking gas has mild clastogenic and hepatotoxic effects. Safety margin of the exposure to this gas must therefore be established as per long-term effects in man.

Table 4: Histological result of mice liver exposed to domestic cooking gas

\begin{tabular}{|c|c|c|}
\hline Group & Treatment & Pathological Changes \\
\hline I & Distilled water & No significant lesion. \\
\hline II & Sodium Arsenite & $\begin{array}{l}\text { Focal collections of } \\
\text { mononuclear cells in the } \\
\text { portal areas. The blood } \\
\text { vessels are markedly } \\
\text { distended. }\end{array}$ \\
\hline III & $\begin{array}{l}\text { Domestic Cooking } \\
\text { Gas }(100 \mathrm{mg} / \mathrm{kg})\end{array}$ & $\begin{array}{l}\text { Several inflammatory } \\
\text { cells aggregated within } \\
\text { necrotic parenchyma }\end{array}$ \\
\hline IV & $\begin{array}{l}\text { Domestic Cooking } \\
\text { Gas }(200 \mathrm{mg} / \mathrm{kg})\end{array}$ & $\begin{array}{l}\text { Distended blood vessels } \\
\text { and centrilobular } \\
\text { hepatocellular } \\
\text { degeneration. }\end{array}$ \\
\hline V & $\begin{array}{l}\text { Domestic Cooking } \\
\text { Gas }(300 \mathrm{mg} / \mathrm{kg})\end{array}$ & $\begin{array}{l}\text { Distended blood vessels } \\
\text { and few foci of } \\
\text { hepatocytic cell necrosis. }\end{array}$ \\
\hline
\end{tabular}

\section{References}

1 Bizzo, W. A.; Calon, B.; Myers, R.; Hanncart, T.: Safety issues for clean liquid and gaseous fuels for cooking in the scope of sustainable development. Energy for Sustainable development. 2004, 8, 60-67.

2 Lloyd, P. J. D.: The safety of paraffin and LP gas appliances for domestic use. J. Energy in South Africa. 2002, 13, 56-61.

3 Kirbride, K. P.; Mannock, C. H.: Fatal respiration of liquefied petroleum gas. Am J. Forens. Med. Pathol. 1992, 13, 353-4.

4 Health Council of Netherland: Committee on Updating of Occupational Exposure Limits. Liquefied Petroleum Gas (LPG), Propane, Butane; Healthbased Reassessment of Administrative Occupational Exposure Limits. The Hague: Health Council of Netherlands, 2004, 2000/150SH/134.

5 Pyatt, J. R.; Gilmore, I.; Mullins, P. A.: Abnormal liver function tests following inhalation of volatile hydrocarbon. Postgrad. Med. J. 1998, 74,747. 
6 Fragides, C. Y.; Tzortz, G. V.; Koulouras, V. et al.: Acute massive rhabdomyolysis due to prolong inhalation of liquid gas. Eur. J. Emerg. Med. 2003, 10, 44-6.

7. Aydin, Y.; Özçakar, L.: Occupational hepatitis due to chronic inhalation of propane and butane gases. Int. J. Clin. Pract., 2003, 57, 546.

8. Fukunaga, T.; Yamamoto, H.; Tanegashima, A. et al.: Liquefied petroleum gas (LPG) poisoning report of two cases and review of literature. Forensic Sci. Int. 1996, 82, 193-200.

9. Occupation Safety and Health and Administration (OSHA). OSHA/EPA Occupation Chemical Data Base, 2006.

10. NIOSH pocket guide to chemical hazard (current through 2006), 2006.

11. Heddle, J.A.; Salmone, M. F.: The micronucleus assay I: In vivo. In: Stitch, H. F. and San, R. H. C eds. Topics in environmental physiology and medicine. Short test for chemical carcinogens. Springerverlay: New York, Heidelberg, Berlin, 1981; pp.243-249.

12. Heddle J. A.; Suhharsan, R. A.; Krepinsky, A. B.: The micronucleus assay II: In vitro. In: Stich, H.F. and San, R.H. C eds. Topics in environmental physiology and medicine. Short test for chemical carcinogens. Springerverlay, New York, Heidelberg, Berlin, 1981; pp. 250-254.

13. Szasz, G.: A kinetic photometric method for serum gamma glutamyl-transferase. Clin. Chem. 1969,124, 124-36.

14. Denekamp, M.; Howarth, M.; Dick, C. A. J.; Cherrie, J. W.; Donaldson, K.; Seaton, A.: Ultrafine particles and nitrogen oxides generated by gas and electric cooking. Occup. Environ. Med. 2001, 58, 511-16.

15. Komura, S.; Ueda, M.; Fujimura, K.: Electroencephalographic studies of liquefied petroleum gas poison in rabbits. Tohoku J. Exp. Med. 1973, 111.

16. Celik, A.; Ogentar, O.; Çömelekoglu, U.: The evaluation of micronucleus frequency using acridine orange fluorescent staining in peripheral blood of rats treated with acetate. Mutagenesis, 2005, 20(6), 411415.

17. Stefano, B.; Ariana, Z.; Marcello, C. et al.: An increased micronucleus frequeny in peripheral blood lymphocytes predicts the risk of cancer in humans. Carcinogenesis, 2007, 28(3), 625-631.

18. Eastmond, D.A.; Tucker, J.D. Identification of aneuploidy inducing agents using Cytokinesisblocked human lymphocytes and antikinetochore antibody. Environ. Mol. Mutagen. 1989, 13, 34-43.

19. Gudi, R. D; Sandhu, S. S.; Athwal, S. R.: Kinetochore identification in Micronuclei in mouse bone marrow erythrocytes. An assay for detection of aneuploidyinducing agent. Mutat. Res. 1990, 234, 263-268.

20. Lum, G.; Gambino, S. R.: Serum gamma glutamyl transpeptidase activity as an indicator of diseases of liver, pancrease or bone. Clin. Chem., 1972, 18, 358.

21. Lee, D. H.; Jacobs, D. R.: Is serum gammaglutamyl transferase a marker of oxidative stress? Free radic. Res., 2004, 38, 535-539.

22. Lee, D. H.; Lim, J. S.; Song, K.; Boo,Y. ; Jacobs, D. R.: Grade association of blood lead and urinary cadmium concentrations with oxidative stress- related markers in the US population. Results from the third National Health and Nutritional Examination survey. Environs. Health Perspect, 2006, 114 (3), 354.

23. Karmaker, R.; Banerjee, A.; Datta, S.; Chatterjee, M. Influence of cadmium intoxification on hepatic lipid peroxidation, glutathione level level and glutathione S- transferase and gammaglutamyl transpeptidase activities: correlation with chromosome aberration in bone marrow cells J. Environ. Pathol. Toxicol. Oncol. 1999, 18, 277-87.

24. Ukaejiofo, E. O.: Biochemical and haematological assessment of workers exposed to some petroleum products in Enugu Urban, Enugu State, Nigeria. Niger J, Med. 2006, 15(2), 151-5.

25. Tsukatmoto, S.; Chiba, S.; Muto, T. et al.: Study on the metabolism of volatile in propane gas (LPG) inhalation- detection of metabolites. Jpn. J. Legal Med. 1985, 39, 124-33.

26. Tsukatmoto, S.; Chiba, S.; Muto, T et al.: Study on the metabolism of volatile hydrocarbon in mice. $J$. Toxicol. Sci. 1985, 10, 323-32.

27. Berzins, T.: n-propane. Nordia, 1995, 28,175-92.

28. Berzins, T.: Butane. Nordia, 1995, 28, 10-26. 